\title{
THE IMPORTANCE OF VILLAGE GOVERNMENT LAW RENEWAL AND ITS IMPLICATIONS TO NAGARI GOVERNANCE IN WEST SUMATERA
}

\author{
Darmini Roza \\ Faculty of Law Universitas Ekasakti Padang \\ E-mail: darmini1955@gmail.com
}

\begin{abstract}
The establishment of Rural Law is mandated by 1945 Constitution which provides recognition, status, law assurance, diversity, democracy and promote rural indigenous cultural traditions. The imple-mentation of Rural Law has implications towards nagari (village) governance which has to adjust it-self to the system and mechanisms stipulated in the Rural Law. Currently, government and West Su-matera Province regional house of representatives (DPRD) has established Regional Regulation draft on Principles of Nagari administration and waiting for Approval by the Ministry of Internal Affairs. The recognition of nagari as a traditional village and law community unit and the Indigenous communities require legal assurance and rights of origin enforcement as well as its authority in the effort of governance implementation and community empowerment. Nagari management prospects is West Sumatera Regional Government agenda to empower villages through village budget aid despite its controversy in terms of maintaining traditional culture of Salingka nagari.
\end{abstract}

Keywords : village, village administration, legal instruments

\begin{abstract}
Abstrak
Lahirnya Undang-Undang Desa merupakan amanat Undang-Undang Dasar Negara Republik Indonesia Tahun 1945 (UUD NRI Tahun 1945) yang memberikan pengakuan, status, kepastian hukum, keanekaragaman, demokrasi serta memajukan adat tradisi budaya masyarakat desa dalam NKRI. Berlakunya Undang-Undang Desa berimplikasi terhadap pemerintahan nagari yang harus menyesuaikan dengan sistem dan mekanisme yang diatur dalam UU Desa. Saat ini Pemerintah bersama DPRD Provinsi Sumatera Barat telah membentuk Rancangan Peraturan Daerah tentang Pokok-Pokok Pemerintahan Nagari dan menunggu Pengesahan dari Kemendagri. Pengakuan keberadaan nagari sebagai desa adat serta kesatuan masyarakat hukum adat dan Lembaga masyarakat Adat perlu kepastian hukum dan penguatan hak asal usul serta kewenangannya dalam rangka penyelenggaraan pemerintahan dan pemberdayaan masyarakat. Prospek penataan Nagari di sebagian Kabupaten merupakan agenda Pemda Sumatera Barat untuk memberdayakan nagari melalui bantuan anggaran Desa sekalipun saat ini masih terjadi pro dan kontra lembaga adat disebagian nagari yang mempertahankan budaya adat salingka nagari.
\end{abstract}

Kata kunci: desa, pemerintah desa, perangkat hukum

Introduction

Reformation Era lasting for fourteen years is like a child who starts to grow up and take care of himself. Similarly, Law Renewal in Indonesia starts with constitutional changes along with other legislation. The amendment is now perceived beneficial, especially in a democracy despite its weaknesses.

According to Henny and Charles, the reformation era brought so many changes to the current government system; the critical public toward the governmental process becomes a challenge for the government to try best for the society welfare. ${ }^{1}$ In this regard, the emergence of the Rural Law is aims to fulfill the Constitution mandate. Inspite of its lateness, there are

\footnotetext{
Henny Andriani dan Charles Simabura, "Implementasi Undang-Undang Nomor 25 Tahun 2009 Tentang Pelayanan Publik Dalam Rangka Mewujudkan Asas Pemerintahan yang Baik (Good Government) Di Provinsi Sumatera Barat", Jurnal Yustisia, Vol. 23 No.1, January-June 2014, Padang: Faculty of Law Universitas Andalas, page 68.
} 
substantial opportunities to realize the ideals of the nation and country living in harmony peace and prosperity. Meanwhile, the Rural Law which was only 2 (two) years described as a breastfeeding-needed baby reflects its government dependancy regardless formal juridically, the central government has given its authority to the village run by the Ministry of Village and under developed Areas. Yet there are still many problems demanding Government attention to direct and supervise the village government. Based on the central government's policy towards rural government institutions, then the question arises, are village governments in Indonesia ready to implement considering unavailable potential, resources and diverse local content and infrastructure on the part of village government?

Article 18 B of 1945 Constitution is the constitutional basis for the establishment of the Rural Law. Previously, Regulation of village government was regulated in Law Number 22 year 1999 which was then replaced by law Number 32 year 2004 on Regional Government and is now replaced by law Number 23 year 2014 on Regional Government yet the entire law do not regulate village administration. In order to implement the mandate of Article 18 B of 1945 Constitution, Law Number 6 year 2014 on village was issued then was followed by Government Regulation Number 43 year 2014 on Regulations Village government implementation as well as Government Regulation Number 60 year 2014 on Village Fund. Rural Law Number 6 year 2014, government Regulation Number 43 Year 2014 and Government Regulation Number 60 year 2014 are the legal renewal of government administration village throughout Indonesia.

West Sumatra province carries out the provisions of Rural Law. Currently, this province comprises 12 (twelve) regencies and 6 (six) towns, while 11 regencies excluding Mentawai Islands regency implement nagari governmental system which cover 648 villages throughout 11 regencies. To the next step, the nagari governance needs enforcement to restore the rights of origin and authority. It is a compulsory to evaluate the given policies to establish the better ones. ${ }^{2}$

Practically, the enactment of the rural law provide an option whether West Sumatra will determine nagari as a traditional village or a nagari government. Currently there are 648 nagari, expected to be increasing in number through the nagari management as long as they are qualified as well as promising village aid for the development and empowerment of rural communities. Accordingly, those problem statements are formulated: first how is the importance of Village Government legal Reform in Indonesia; and second, how are the implications for nagari administration in West Sumatra.

\section{Discussion}

Rural Law as Legal Reform in Indonesia

Article 18 B of paragraph (1) and (2) 1945 Constitution explained that the State shall acknowledges and respects the units of regional administration as regulated by the law. The State acknowledges and respects units of indigenous communities and their traditional rights as long as they live, and in accordance with the development of society and the principles of the Unitary Republic of Indonesia stipulated in the law.

The basic constitution provides authority to the village as a traditional law community unit including Nagari in West Sumatra to organize and manage their own administration and financial management independently. The establishment of the Rural Law is law reform on the existence of the village, as well as village empowerment as part of the regional autonomy implementation and as evidence of the Government's concern to the regions, especially the village. This fact differentiates new order era from reforms order in terms that regional autonomy is implemented under State control by

\footnotetext{
Disty Sulistiani, Edi Susilo, Aan Eko Widiarto, "Efektivitas Pengelolaan Hutan Mangrove Dalam Perspektif Hukum dan Sosial Masyarakat Pesisir Kabupaten Trenggalek", Jurnal Arena Hukum No. 1 Year 1, January 2008, Malang: Faculty of Law Universitas Brawijaya, page 93.
} 
focusing on self-reliance, especially in rural areas. $^{3}$

Renewal is desirable and urgent necessity regarding the rule of law functions as a regulatory tool or means of development that determines society towards the desired condition. ${ }^{4} \mathrm{AC}$ cording to Didik Sukriono in M.Iwan Satriawan, there are two village concepts: first, a acknowledged village that is the village of indigenous people's referred to by the names of the local; and second, a formed village, that is the village acknowledged by the government under the law, the village is seen as a regional entity in which resides a community which has the authority to run their own government. ${ }^{5}$

Along with these opinions, according to the Rural Law, village is divided into two (2) systems, the official (government) village and the traditional village. Traditional villages have distinct characteristics mainly due to its strong indigenous influences on the local government system, the management of local resources and social and cultural life of rural communities. Traditional Village in principle constitutes customary law community unit based on the genealogical and territorial combination preserved over generations. Implementation of customary law community unit has lived in the territory of the Republic of Indonesia as huta/ Nagori in North Sumatra, gampong in Aceh, nagari in $\mathrm{Mi}$ nangkabau, marga in South Sumatra, tiuh or pekon in Lampung, palkraman in Bali, lembang in Toraja, banua and wanua in in Kalimantan and Negeri in Maluku province. The existence of Indigenous villages have been stated in the elucidation of 1945 constitution which means that long before this constitution, traditional villages have been there and become a historical record

3 Yusnani Hasjimzoem, "Dinamika Hukum Pemerintahan Desa", Jurnal Fiat Justisia Ilmu Hukum, Vol. 8 No. 3, July-September 2014, Lampung: Faculty of Law Universitas Lampung, page 473.

4 M Galang Asmara, Arba dan Yanis Mulyadi, "Penyelesaian Konflik Pertanahan Berbasis Nilai-nilai Kearifan Lokal di Nusa Tenggara Barat", Jurnal Mimbar Hukum, Vol. 22 No. 1, February 2010, Yogyakarta: Faculty of Law Universitas Gadjah Mada, page 23.

5 M Iwan Sastriawan, "Politik Hukum Pemerintahan Desa di Indonesia", Fiat Justisia Jurnal IImu hukum. Vol. 7 No. 2, August-May 2013 Edition, Lampung: Faculty of Law Universitas Lampung, page 152. for the village government in Indonesia preserved by the customary law community until now.

Legal Reform of the village administration is a government policy aimed at giving authority to the village government. In local governance implementation, public policy and law play a very important role. The discussion of the law covers two aspects: justice concerning public to be equally treated before the law and the legal aspects (the positive law). ${ }^{6}$ In addition, there are important issues, that is the presence of State and local governments in the form of public service fulfillment to all citizens basic rights in the region. ${ }^{7}$ Thus, the State as the authorities and the law as the basis of power and authority carried out for citizen interest. Related to legal positivism, law is the sovereign power commands (John Austin) and the will of the State (Hans Kalsen) in his theory of Analogical Jurisprudence, or analytical legal theory; there are two forms of law, the first, positive law (Law) and the second, positive morality (customary Law). ${ }^{8}$ Furthermore, the German sociological jurisprudence (Eugen Ehrlich) and developed in the United States (Roccoe Pound) stated that laws are made to give Living Law a concern means that this view acknowledges the source of formal law both legislation and not in accordance with the living law. ${ }^{9}$

Based on those theories and related to the legal reform on the rural law which conforms village systems across Indonesia, it is acceptable and adjustable to the legal culture of indigenous people. This new law can influence positive morality (customary law) that live and develop within community such as nagari, especially the Minangkabau with their customary law and deliberation as a tool of democracy that remain as a living law. Deliberation for indigen-

Otong Rosadi, "Sinergitas Pencegahan dan Pemberantasan Korupsi, Posisi dan Peran Pendidikan Tinggi”, Joernal of Low, Vol. 1 No. 1, June 2016, Padang: Faculty of Law Universitas Ekasakti, page 33.

7 Edi Wibowo, 2004, Hukum dan Kebijakan Publik, Yogyakarta: Yayasan Pembaharuan Administrasi publik Indonesia, page 18

8 Otje Salman,1992, Ikhtisar Filsafat Hukum, Bandung: Armico, page 13.

9 Ibid, page 15 
ous peoples becomes the heart of democracy that still survives to this day. ${ }^{10}$

Rural Law is the foundation of the village administration and it is attributive and constitutive authority. The village government is led by a village chief and assisted by village officials and village government as well as Village Consultative Body. The village authority includes administration of the village, the implementation of rural development, guidance and empowerment of rural communities based on community initiatives, right of origin and customs of the village.

\section{Implications of Rural Law Implementation on Nagari Governance in West Sumatra}

Implementations of Rural Law cause all laws of West Sumatera government, both provincial and district regulations as well as regulations governing the regional head village to be inapplicable or legal vacuum. To adapt Rural Law, West Sumatera government has proposed Rural Regulation drafts which is currently approval await of Ministry of Internal Affairs. Nagari Government is the implementation of government affairs by the nagari government and Village Custom to regulate and manage the interests of local communities respected by Indonesian government system Indonesia.

Village government as the lowest government led by a wali nagari, and assisted by a wali jorong, wali jorong as an extension authority in governance system management and a nagari secretary (setnag). Wali nagari selected by the anak nagari (the villagers) democratically. ${ }^{11}$

In running the village government system, it cannot be separated from the local values. In fact, village government is the origin of Minangkabau Custom Government. ${ }^{12}$ As Minangkabau's

10 Saafroedin Bahar dan Riswiati Suryaputra, "Kebijakan Negara dalam Rangka Pengakuan, Penghormatan dan Perlindungan Masyarakat Hukum Adat", Jurnal Ilmu Hukum Menara Yuridis, Vol. 2 No. 2, July 2010, Bukittinggi: Faculty of Law UMSB, page 79.

11 Darmini Roza, "Tinjauan tentang Pemberlakuan UndangUndang Desa di Sumatera Barat". LAWREFORM jurnal ilmiah Hukum \& Pembangunan Vol. IV No. 2, February 2015, Jakarta: Postgraduate of Law Science Universitas Bung Hatta, page 77.

12 Yance Arizona, "Konstitusionalitas Noken: Pengakuan Model Pemilihan Masyarakat Adat dalam Sistem Pemilihan Umum di Indonesia", Jurnal Konstitusi, Vol. III No. 1,
Community, the basic philosophy customs and culture of Minangkabau relied to basandi syara' Syara' basandi Kitabullah custom, Syara' mangato adat mamakai, salingka nagari custom is adhered and passed over generation to keep the sustainability in West Sumatra. Recognition, respect and protection of the State towards indigenous peoples is not taken for granted but it is obtained through planned and organized struggle. ${ }^{13}$ Village is the lowest system in implementing government affairs either the existing ones or handed autonomy by the government, village is considered as executive co-administration of upper government. ${ }^{14}$

Kerapatan Adat Nagari (KAN), as a nonformal institution in village government consists of tungku tigo sajarangan. Tungku tigo sajarangan is native representative consisting of clerics, scholars (intellectuals) and niniak mamak (tribal leaders in the village). In addition, it plays role as a justice of the peace for children's nephew when sako jo pusako dispute happens, also in the process of registration of Tanah Ulayat Adat.

As a custom public institution, Kerapatan Adat Nagari has functions: first, to promote the implementation of the Nagari Government, such as tax charge and dissemination in raising awareness of the taxpayer; secondly, to share ideas to develop village in terms of public education and guidance to children school dropouts; and third, to participate in the development in village as village community empowerment. Kerapatan Adat Nagara Institution is influencial to nagari governance both community empowerment and custom-related matters. ${ }^{15}$

June 2010, Padang: Pusako Universitas Andalas, page 118-119.

13 Febriyadi, "Eksistensi Pemerintahan Nagari di Sumatera Barat Pasca UU Desa No. 6 Tahun 2014 di Kabupaten Sijunjung dan Padang Pariaman", Swara Yustisia, Vol. 1 Year 13, April 2015, Padang:Faculty of Law Universitas Ekasakti, page 113.

14 Yuslim, "Mewujudkan Otonomi Nagari Melalui Tugas Pembantuan Dari Pemerintah Provinsi", Jurisprudentia, Jurnal Ilmiah Ilmu Hukum, No. 3, January 2010, Jakarta: Faculty of Law Universitas Bung Hatta, page 126.

15 Darmini Roza, 2005, Eksistensi dan Mekanisme Penyelenggaraan Pemerintahan Nagari di Era Otonomi Daerah dan Prospeknya di Sumatera Barat, Disertasi, Bandung: Universitas Padjadjaran, page 277. 
As the lowest administration system, $\mathrm{Na}$ gari is authorized by legislation to issue nagari law. Regional law functions to provide guidance of local/nigari governance. ${ }^{16}$ In addition, Village Consultative Body serves as an element of Nagari government and together with wali nagari compose a nagari law. Nagari has its territory and limit as well as political structures and apparatus and some requirements that must be met by a settlement to become a nagari including customs hall, mosques, markets and supported by paddy fields. ${ }^{17}$ The alliance of minangkabau community customary law who gathered in village community reoriented to live monosyllabic, communal, and gathered. ${ }^{18}$

With the approval of Rural Law, it is expected to provide fresh air to both society and government itself, increase and a change towards the betterment in governance as well as in the management of village budget. Draft of Regional Regulation of West Sumatra Province needs to adjust the substance of the Rural Law, reform concept of the nagari government such as empowering Wali nagari authority as the one who responsible for financial management of Village. Dealing with financial management, wali nagari is assisted by nagari assistant. Operationally, village government is financed by state budget revenues. Wali Nagari together with Kerapatan Adat Nagari set a revenue budget expenditure, while the source of village income is not taken over by the provincial and district governments. Moreover, it forms a nagari Court as an institution of dispute resolution between the public and ensure the enforcement of statutory, basandi syara' syara' basandi kitabullah custom, State Laws and Salingka nagari custom.

16 Nirmala Sari, "Peranan Pemerintah Propinsi Jambi dalam Pengawasan Terhadap Peraturan Daerah Kabupaten/Kota Berdasarkan UU 32/2004", Jurnal Erudisi Wahana Pengkajian Sosial dan Politik, Vol. 2 No. 3, December 2012, Semarang:Faculty of Social Science and Political Science Universitas Negeri Semarang, page 632

17 Darmini Roza, .. Op.cit page 78.

18 Emi Handrina, "Pemerintahan Nagari di Era Orde Baru", Jurnal Erudisi Wahana Pengkajian Sosial dan Politik, Vol. 1 No. 3, December 2011, Padang:Faculty of Social Scince and Political Science Universitas Ekasakti, page 232.
Further, Rural Law assures governance implementation both from political aspects as well as financial and culture aspects, when compared to the previous provisions. The formation of this Law basically aims to achieve a state of growth and long-term improvement and qualitative improvement to the citizen's way of life. It is a pattern that affects the development of the mental aspects, physical (body), intelligence and the awareness of society and the state. However, the achievement of rural development ibjectives and target are basically determined by the mechanisms and structures used as the rural development system.

One of the aims of legal reform is for the development of all aspects both physical and mental needs balance between village government and society. The Rural Law contains the development and improvement of village government authority. This law confirms the Village Administration, the development implementation, social development and community empowerment.

For its development, Rural Law is believed to provide much greater benefits for the region, especially rural development. Additionally, the substance regulated by Rural Law accommodate the village called Traditional Village. By the establishment of Rural Law, it will open the opportunities for West Sumatera to shift the government structure referring to the Traditional Village. Rural Law is very beneficial for the region and accommodate the peculiarities of naming their village or another name that is like a legal basis uses the term Nagari in West Sumatera, as well as related to Central Government financial assistance to the Village/Nagari. Due to different budget for each country, it is according to the area composition and the availability of infrastructure.

To improve the governance quality, Government concerns to provide facilities that will help the Village Head to manage the budget and village allocation fund are required. Reform of Rural Law is very favorable to the Village and the Village Apparatus both with regard to local values/traditional right and budget allocation given to the village by the District Government, 
providing the opportunity for regions to organize and manage the interests of the public, improve services and prosperity of community. ${ }^{19}$

As the lowest level goverment, the village is a unit of community that has boundaries authorized to regulate and manage the interests of local communities, based on the origin, local customs that is recognized and respected within Indonesian government systems. ${ }^{20}$ Fundamental thoughts of Village Government are diversity, participation, autonomy, democratization and community empowerment.

Related to the village autonomy, 1945 Constitution implicitly confirms that Indonesia's cultural identity and the rights of traditional communities are in line with civilization. ${ }^{21}$ In this case, the rights of indigenous people must not only be interpreted as a partial right, for instance, economic sector, but should be viewed comprehensively, which includes the rights of political, social, legal, cultural, and so forth included rights to form a government based on the culture and customs that have historically been prevailing in the local community. ${ }^{22} \mathrm{Re}$ cognition and protection of village autonomy is also constitutionally affirmed in Article $18 \mathrm{~B}$ Paragraph (2) of 1945 Constitution.

Village-owned authonomy is based on the origins and customs, not based on the delegation of authority from the Government. Village village is a community unit which has the authority to regulate and manage local community interest based the origins and local customs which is acknowledged by National Government system. The authority to organize and manage the local community based on the origin and local customs indicates that customary law communities are acknowledged. ${ }^{23}$ The village self-

19 Kamal Hijaz, “Implementasi Penyelenggaraan Kewenangan Pemerintahan Daerah di Indonesia", Jurnal Ilmu Hukum Amanna Gappa, Vol. 18 No. 1, March 2010, Makasar:Faculty of Law Universitas Hassanudin, page 33.

20 Ateng Syafrudin and Suprin Na'a, 2010, Republik Desa Pergulatan Hukum Tradisional dan Hukum Modern Dalam Desain Otonomi Daerah, Bandung: Alumni, page 3.

21 Paragraph I of Article 28 (3) of the Constitution of the Republic of Indonesia Year 1945.

22 Ateng Syafrudin and Suprin Na'a, Op.Cit, page 12.

23 Hartati and Helmi, "Bentuk Hukum Pengukuhan Masyarakat Hukum Adat dalam Rangka Pengelolaan Hutan", Jurnal Mahkamah Konstitusi, Vol. 20 No. 1, April 2008, Jakarta: Mahkamah Konstitusi RI, page 30. dependence is one of the principles of village arrangement in which a process conducted by the village government and village communities to perform an activity in order to meet self reliance.

\section{Conclusion}

Legal Reform of village government is mandated by the 1945 Constitution. Rural Law opens up opportunities for more independent village both in implementing the system of government and in the management of the budget by the state. The position of village in the government system as the base of the central government which is located in the district and participate to implement the aims of the country to realize people welfare, economic equality and development as a form of recognition from the State. The village diverse, both supra structure and resources along with the cultural rights of their origins in villages are different. Thus, government concern in order to continuously control and guidance are required. By the issue of the Rural Law, there is a legal vacuum in the province of West Sumatra. Currently the Government of West Sumatera with DPRD are already discussing the Proposed Local Regulation on Nagari Government and awaiting approval from the Ministry of Internal Affairs.

\section{Suggestion}

To maintain local wisdom, the contents of Rural Regulations Draft must agree the name of nagari or other name of the village, and determine the choice of the custom village and enforcement of Kerapatan Adat Nagari (KAN) authority as well as the establishment of the Village Court functioning to solve the disputes in Village. For the future, yet, Nagari management prospect is expected to create a equitable development, nagari empowerment and social welfare through the village budget supported by the government.

\section{References}

Andriani, Henny and Charles Simabura. "Implementasi Undang-Undang Nomor 25 Tahun 2009 Tentang Pelayanan Publik Dalam Rangka Mewujudkan Asas Pemerintahan 
yang Baik (Good Government) Di Provinsi Sumatera Barat". Jurnal Yustisia. Vol. 23 No. 1. January-June 2014. Padang: Faculty of Law Universitas Andalas;

Arizona, Yance. "Konstitusionalitas Noken: Pengakuan Model Pemilihan Masyarakat Adat dalam Sistem Pemilihan Umum di Indonesia". Jurnal Konstitusi. Vol. III No. 1. June 2010. Padang: Pusako Universitas Andalas;

Asmara, M. Galang. Arba and Yanis Mulyadi. "Penyelesaian Konflik Pertanahan Berbasis Nilai-nilai Kearifan Lokal di Nusa Tenggara Barat”. Jurnal Mimbar Hukum. Vol. 22 No. 1. February 2010. Yogyakarta: Faculty of Law Universitas Gadjah Mada;

Bahar, Saafroedin and Riswiati Suryaputra. "Kebijakan Negara dalam Rangka Pengakuan. Penghormatan dan Perlindungan Masyarakat Hukum Adat". Jurnal Ilmu Hukum Menara Yuridis. Vol. 2 No. 2. July 2010. Bukittinggi: Faculty of Law UMSB;

Febriyadi, "Eksistensi Pemerintahan Nagari di Sumatera Barat Pasca UU Desa No. 6 Tahun 2014 di Kabupaten Sijunjung dan Padang Pariaman". Swara Yustisia. Vol.1 Year 13. April 2015. Padang: Faculty of Law Universitas Ekasakti;

Handrina, Emi. "Pemerintahan Nagari di Era Orde Baru". Jurnal Erudisi Wahana Pengkajian Sosial dan Politik. Vol. 1 No. 3. December 2011. Padang: Faculty of Social Science and Political Science Universitas Ekasakti;

Hartati dan Helmi. "Bentuk Hukum Pengukuhan Masyarakat Hukum Adat dalam Rangka Pengelolaan Hutan". Jurnal Mahkamah Konstitusi. Vol. 20 No. 1. April 2008. Jakarta: Mahkamah Konstitusi RI;

Hasjimzoem, Yusnani. "Dinamika Hukum Pemerintahan Desa". Jurnal Fiat Justisia IImu Hukum. Vol. 8 No. 3. July-September 2014. Lampung: Faculty of Law Universitas Lampung;

Hijaz, Kamal. "Implementasi Penyelenggaraan Kewenangan Pemerintahan Daerah di Indonesia". Jurnal Ilmu Hukum Amanna Gappa. Vol. 18 No. 1. March 2010. Makassar: Law Faculty Universitas Hassa-nudin;

Rosadi, Otong. "Sinergitas Pencegahan dan Pemberantasan Korupsi. Posisi dan Peran Pendidikan Tinggi”. Joernal of Low. Vol. 1
No. 1. June 2016. Padang: Faculty of Law Universitas Ekasakti;

Roza, Darmini. 2005. Eksistensi dan Mekanisme Penyelenggaraan Pemerintahan Nagari di Era Otonomi Daerah dan Prospeknya di Sumatera Barat. Disertasi. Bandung: Universitas Padjadjaran;

-...-.-,"Tinjauan tentang Pemberlakuan UndangUndang Desa di Sumatera Barat". LAW REFORM jurnal ilmiah Hukum \& Pembangunan. Vol. IV No. 2. February 2015. Jakarta: Postgraduate of Faculty of Law Science Universitas Bung Hatta;

Roza, Darmini and Nasrul. "Peran Serta KAN dalam Proses Pendaftaran Tanah Tanah Ulayat Adat pada Kantor pertanahan Kab Solok". Swara Yustisia. Vol. 1 Year 10. April 2012. Padang: Faculty of Law Universitas Ekasakti;

Salman, Otje.1992. Ikhtisar Filsafat Hukum. Bandung: Armico;

Sari, Nirmala. "Peranan Pemerintah Propinsi Jambi dalam Pengawasan Terhadap Peraturan Daerah Kabupaten/Kota Berdasarkan UU 32/2004". Jurnal Erudisi Wahana Pengkajian Sosial dan Politik. Vol. 2 No. 3. December 2012. Semarang: Faculty of Social Science and Political Sciene Universitas Negeri Semarang

Sastriawan, M. Iwan. "Politik Hukum Pemerintahan Desa di Indonesia". Fiat Justisia Jurnal Ilmu hukum. Vol. 7 No. 2. AugustMay 2013 edition. Lampung: Faculty of Law Universitas Lampung;

Sulistiani, Disty. Edi Susilo. Aan Eko Widiarto. "Efektivitas Pengelolaan Hutan Mangrove Dalam Perspektif Hukum dan Sosial Masyarakat Pesisir Kabupaten Trenggalek". Jurnal Arena Hukum. No. 1 of 1. January 2008. Malang: Faculty of Law Universitas Brawijaya;

Syafrudin, Ateng and Suprin Na'a. 2010. Republik Desa Pergulatan Hukum Tradisional dan Hukum Modern Dalam Desain 0 tonomi Daerah. Bandung: Alumni;

Wibowo, Edi. 2004. Hukum dan Kebijakan Publik. Yogyakarta: Pembaharuan Administrasi Publik

Yuslim, "Mewujudkan Otonomi Nagari Melalui Tugas Pembantuan Dari Pemerintah Provinsi". Jurisprudentia. Jurnal Ilmiah Ilmu Hukum. No. 3. January 2010. Jakarta: Faculty of Law Universitas Bung Hatta. 